\title{
Milkborne general outbreaks of infectious intestinal disease, England and Wales, 1992-2000
}

\author{
I. A. GILLESPIE ${ }^{1 *}$, G. K. ADAK ${ }^{1}$, S. J. O’BRIEN ${ }^{1}$ AND F. J. BOLTON ${ }^{2}$ \\ ${ }^{1}$ PHLS Communicable Disease Surveillance Centre, 61 Colindale Avenue, London NW9 5EQ \\ ${ }^{2}$ PHLS Central Public Health Laboratory, 61 Colindale Avenue, London NW9 5EQ
}

(Accepted 28 January 2003)

\section{SUMMARY}

From 1 January 1992 to 31 December 2000, 27 milkborne general outbreaks of infectious intestinal disease (IID) were reported to the Public Health Laboratory Service (PHLS) Communicable Disease Surveillance Centre (CDSC). These outbreaks represented a fraction $(2 \%)$ of all outbreaks of foodborne origin $(N=1774)$ reported to CDSC, but were characterized by significant morbidity. Unpasteurized milk (52\%) was the most commonly reported vehicle of infection in milkborne outbreaks, with milk sold as pasteurized accounting for the majority of the rest (37\%). Salmonellas (37\%), Vero cytotoxin-producing Escherichia coli (VTEC) O157 (33\%) and campylobacters $(26 \%)$ were the most commonly detected pathogens, and most outbreaks were linked to farms $(67 \%)$. This report highlights the importance of VTEC O157 as a milkborne pathogen and the continued role of unpasteurized milk in human disease.

\section{INTRODUCTION}

Milk forms an important part of our diet, and this is reflected in production levels: between 34 and 42 million litres of milk are produced daily in the United Kingdom [1] to provide the 11 thousand million pints sold for liquid consumption each year [2]. In order to meet this demand, intensive methods have been developed both on the farm and at the dairy. For example, the dairy cow of today produces more than twice the amount of milk per year than her ancestor did at the end of the Second World War and 1200 litres more than a dairy cow did 20 years ago [2]. Furthermore, between 1956 and 1994 the number of registered dairy holdings in the United Kingdom (UK) fell from 170000 to 37000 , whilst the average volume of milk sold per annum rose from 25000 to 370000 litres per farm [3]. Such transitions could have important public health consequences, as there is greater potential for

\footnotetext{
* Author for Correspondence.
}

infecting a larger number of people should control measures fail.

Milk has, until relatively recently, been considered a common source of disease. Between 1912 and 1937 about 65000 deaths from bovine tuberculosis were reported in England and Wales, and milk was associated with many cases of brucellosis, typhoid fever, paratyphoid fever, food poisoning and other diseases [4]. Eradication programmes from the 1950s to the 1980s, and the adoption of pasteurization by the majority of the milk industry, has meant that milkborne disease is now relatively rare [5].

Recent European legislation [6], adopted into UK law [7], has aimed to further ensure the safe production and marketing of milk and milk products. Under the regulations, raw and heat-treated milk should be free from pathogenic micro-organisms. The law is based on a system of registration of production holdings and approval of dairy establishments, and enforcement is carried out through inspection by food authorities. Non-compliance with the regulations can 
ultimately lead to the removal of registration or approval, meaning that production activities would have to cease at the premises concerned [8].

Such initiatives, interventions and legislation mean that milk is probably safer now than ever before. However, concerns about its microbiological safety still exist, with notable milkborne outbreaks of infectious intestinal disease occurring both at home and abroad in recent years. In the largest outbreak of Vero cytotoxin-producing Escherichia coli (VTEC) O157 infection in England and Wales to date, 114 people were ill and 28 people were admitted to hospital in February 1999 following the consumption of improperly pasteurized milk from a local dairy in North Cumbria [9]. Furthermore, over 14500 were ill and at least 180 were hospitalized in Japan in 2000 as a result of ingesting a nationally distributed milk product [10]. Investigations at the process plant revealed that the low-fat milk became contaminated with Staphylococcus aureus from a valve of the pipe leading to one of the production tanks.

In order to assess the current role of milk in foodborne illness, we have focussed on milkborne general outbreaks of IID reported to the Communicable Disease Surveillance Centre between 1992 and 2000.

\section{METHODS}

The sources of routinely collected data on food poisoning in England and Wales have been described in detail previously $[11,12]$. The system of surveillance for general outbreaks of IID is based on a standard questionnaire, which is issued to the lead investigator following the initial report of an outbreak. The questionnaire, which is completed when the outbreak is over, seeks a minimum dataset, including details of the setting (it is important to note that, in foodborne outbreaks, where a food is prepared takes precedence over where it is served), mode of transmission, causaive organism, and details of epidemiological and laboratory investigations [13]. Returned questionnaires are stored in a dynamic database derived from Epi Info version 5 [14].

Outbreaks were selected where food was thought to be the primary route of transmission (in some outbreaks foodborne transmission is followed by personto-person transmission) and where milk was identified as the suspected vehicle of infection. Comparisons within this group, and between this group and other outbreaks of foodborne origin, were undertaken. Descriptive and statistical analysis of the data was under taken using Microsoft Excel, Epi Info version 5 and Stata version 7 (Stata Corporation). Relative proportions and relative proportions over time were compared using the $\chi^{2}$ test and the $\chi^{2}$ test for trend respectively. For smaller samples Fisher's exact test was used. Means were compared using Student's $t$ test.

\section{RESULTS}

From 1 January 1992 to 31 December 2000, the Public Health Laboratory Service (PHLS) Communicable Disease Surveillance Centre (CDSC) received initial reports on 8104 general outbreaks of IID. Further investigation (at the local level) revealed that $1009(12 \%)$ of these were not in fact outbreaks or had occurred abroad. Of the remaining 7095, 5257 completed outbreak forms were received (response rate $74 \%$ ) and entered onto the database (Table 1). In 1774 (34\%) of these 5257 outbreaks food was thought to be the primary route of transmission (for 256 of these outbreaks foodborne transmission was followed by person-to-person transmission). In 27 (2\%) of these, milk was reported as a likely vehicle of infection.

\section{Evidence}

More than one form of evidence implicating milk was supplied for 7 outbreaks and in 1 outbreak the type of evidence obtained was not reported. Microbiological evidence (the isolation of the causative organism from milk) was reported in 12 outbreaks, evidence from a cohort study in 5 and from a case-control study in 8 outbreaks. Descriptive epidemiology was reported in 16 outbreaks. Microbiological evidence (44\%) and evidence from a case-control study $(30 \%)$ were more likely to be reported in milkborne outbreaks compared with those associated with other foods (15\% and $6 \%$ respectively) $(P<0.001$ and $P<0.001$ respectively).

\section{Type of milk product}

Unpasteurized milk $(14 / 27 ; 52 \%)$ was the most commonly reported vehicle of infection in milkborne outbreaks, with milk sold as pasteurized accounting for the majority of the rest $(10 / 27 ; 37 \%)$. Bird-pecked milk (pasteurized milk, contaminated when birds peck through the external container) was thought to have caused the observed illness in one outbreak and in two outbreaks more than one milk type (milk sold as pasteurized and unpasteurized; unpasteurized and pasteurized bird-pecked) was implicated. 
Table 1. General outbreaks, outbreaks of foodborne origin, and milkborne outbreaks of infectious intestinal disease, England and Wales, 1992-2000

\begin{tabular}{lccc}
\hline \hline Year & $\begin{array}{l}\text { All general } \\
\text { outbreaks }\end{array}$ & $\begin{array}{l}\text { Outbreaks of } \\
\text { foodborne origin* }(\% \dagger)\end{array}$ & $\begin{array}{l}\text { Milkborne } \\
\text { outbreaks }(\% \dagger)\end{array}$ \\
\hline 1992 & 373 & $232(62)$ & $4(2)$ \\
1993 & 454 & $243(54)$ & $3(1)$ \\
1994 & 490 & $239(49)$ & $4(2)$ \\
1995 & 837 & $233(28)$ & $4(2)$ \\
1996 & 733 & $202(28)$ & $4(2)$ \\
1997 & 591 & $249(42)$ & $3(1)$ \\
1998 & 609 & $142(23)$ & $2(1)$ \\
1999 & 516 & $116(22)$ & $2(2)$ \\
2000 & 654 & $118(18)$ & 27 \\
Total & 5257 & $1774(34)$ & \\
\hline \hline
\end{tabular}

* Foodborne outbreaks and foodborne outbreaks followed by person-to-person transmission; $\dagger$ of all general outbreaks; $\ddagger$ of all outbreaks of foodborne origin.

Table 2. The role of pathogens and toxins in milkborne general outbreaks of infectious intestinal disease, England and Wales, 1992-2000

\begin{tabular}{|c|c|c|c|}
\hline \multirow[b]{2}{*}{ Pathogen/toxin } & \multicolumn{2}{|c|}{ Number of outbreaks (\%) } & \multirow[b]{2}{*}{ Tota } \\
\hline & Milkborne outbreaks & Other outbreaks & \\
\hline VTEC* O157 & $9(33)$ & $45(3)$ & 54 \\
\hline Campylobacters & $7(26)$ & $49(3)$ & 56 \\
\hline$S \dagger$. Typhimurium & $6(22)$ & $110(6)$ & 116 \\
\hline$S$. Enteritidis PT4 & $2(7)$ & $505(29)$ & 507 \\
\hline Other salmonellas & $2(7)$ & $67(4)$ & 69 \\
\hline$S$. Enteritidis & 0 & $151(9)$ & 151 \\
\hline Noroviruses: & 0 & $184(11)$ & 184 \\
\hline Staphylococcus aureus & 0 & $24(1)$ & 24 \\
\hline Cryptosporidium & $1(4)$ & $2(0 \cdot 1)$ & 3 \\
\hline Shigella sonnei & 0 & $4(0 \cdot 2)$ & 4 \\
\hline Sh.flexneri & 0 & $2(0 \cdot 1)$ & 2 \\
\hline Clostridium perfringens & 0 & $190(11)$ & 190 \\
\hline Rotavirus & 0 & $4(0 \cdot 2)$ & 4 \\
\hline Scombrotoxin & 0 & $51(3)$ & 51 \\
\hline Bacillus cereus & 0 & $35(2)$ & 35 \\
\hline Astrovirus & 0 & $4(0 \cdot 2)$ & 4 \\
\hline$S$. Virchow & 0 & $19(1)$ & 19 \\
\hline B. subtilis & 0 & $8(0 \cdot 5)$ & 8 \\
\hline Other & 0 & $14(1)$ & 14 \\
\hline Unknown & 0 & 279 (16) & 279 \\
\hline Total & 27 & 1747 & 1774 \\
\hline
\end{tabular}

* Vero cytotoxin-producing Escherichia coli; † Salmonella enterica serovar;

$\$$ formally Norwalk-like viruses.

\section{Pathogens}

The pathogens most commonly implicated in milkborne outbreaks of IID were salmonellas (Salmonella enterica serovar Typhimurium (6), S. Enteritidis PT4 (2), $S$. Anatum (1), S. Java (1); 37\%), VTEC O157
$(33 \%)$ and campylobacters $(26 \%)$ (Table 2$)$. Vero cytotoxin-producing E. coli O157, campylobacters and $S$. Typhimurium were more commonly implicated in milkborne outbreaks compared with other outbreaks of foodborne origin $(3 \%, 3 \%$ and $6 \%$ respectively) $(P<0 \cdot 001, P<0 \cdot 01$ and $P<0.001$ respectively). 
Table 3. Milkborne general outbreaks of infectious intestinal disease, England and Wales, 1992-2000. Milk types in relation to pathogen

\begin{tabular}{|c|c|c|c|c|c|}
\hline \multirow[b]{2}{*}{ Pathogen } & \multicolumn{4}{|c|}{ Number of outbreaks } & \multirow[b]{2}{*}{ Total } \\
\hline & Unpasteurized & Pasteurized* & Mixed $\dagger$ & Bird-pecked & \\
\hline VTEC $\$$ O157 & 5 & 3 & 1 & 0 & 9 \\
\hline Campylobacters & 4 & 1 & 1 & 1 & 7 \\
\hline$S \S$. Typhimurium & 5 & 1 & 0 & 0 & 6 \\
\hline$S$. Enteritidis PT4 & 0 & 2 & 0 & 0 & 2 \\
\hline Other salmonellas & 0 & 2 & 0 & 0 & 2 \\
\hline Cryptosporidium & 0 & 1 & 0 & 0 & 1 \\
\hline Total & 14 & 10 & 2 & 1 & 27 \\
\hline
\end{tabular}

* Milk sold as pasteurized; $\dagger$ in one outbreak a mixture of milk sold as pasteurized and unpasteurized milk was reported, in the other a mixture of unpasteurized milk an bird pecked pasteurized milk was reported, $\$$ Vero cytotoxin-producing Escherichia coli; $\S$ Salmonella enterica serovar.

Table 4. Milkborne general outbreaks of infectious intestinal disease, England and Wales, 1992-2000. Distribution by source

\begin{tabular}{lllr}
\hline \hline & \multicolumn{2}{l}{ Number of outbreaks $(\%)$} \\
\cline { 2 - 3 } & $\begin{array}{l}\text { Milkborne } \\
\text { Place }\end{array}$ & $\begin{array}{l}\text { Other } \\
\text { outbreaks }\end{array}$ & \multicolumn{1}{c}{ Total } \\
\hline Armed services & $1(4)$ & $39(2)$ & 40 \\
Canteen & 0 & $72(4)$ & 72 \\
Community & $3(11)$ & $21(1)$ & 24 \\
Farm & $18(67)$ & $7(<1)$ & 25 \\
Hall/caterers & 0 & $86(5)$ & 86 \\
Holiday camp & 0 & $11(1)$ & 11 \\
Hospital & 0 & $48(3)$ & 48 \\
Hotel & 0 & $226(13)$ & 226 \\
Mobile & 0 & $13(1)$ & 13 \\
Other & $1(4)$ & $90(5)$ & 91 \\
Private & 0 & $200(11)$ & 200 \\
Pub/bar & 0 & $109(6)$ & 109 \\
Residential & 0 & $226(13)$ & 226 \\
Restaurant & 0 & $400(23)$ & 400 \\
School & $4(15)$ & $75(4)$ & 79 \\
Shop/retailer & 0 & $106(6)$ & 106 \\
University/college & 0 & $18(1)$ & 18 \\
Total & 27 & 1747 & 1774 \\
\hline \hline
\end{tabular}

There were no statistical differences between the distribution of pathogens in milk implicated in outbreaks between milk sold as pasteurized or unpasteurized (Table 3).

\section{Morbidity and mortality}

A total of 662 people was affected in the milkborne outbreaks, with 67 hospital admissions reported but no deaths. Whilst the average number of people affected (25) was no higher than in other outbreaks of foodborne origin (23) $(P>0 \cdot 05)$, the risk of hospital admission was far greater $(0 \cdot 10$ vs. 0.03 ; Risk Ratio (RR) 2.95; 95\% Confidence Interval (CI) 2.34-3.72; $P<0 \cdot 001)$. One outbreak accounted for a large number of the hospital admissions: 28 people were admitted in an outbreak of VTEC O157 infection associated with milk sold as pasteurized in the North West of England [9]. However, when this outbreak was excluded, the increased risk of hospital admission remained (RR $1 \cdot 84 ; 95 \%$ CI $1 \cdot 35-2 \cdot 49 ; P<0 \cdot 001$ ). Within the different milk types there were no differences with regard to size or the risk of hospitalization.

\section{Outbreak setting}

The majority of milkborne outbreaks occurred on or were linked to farms compared with other outbreaks of foodborne origin $(67 \% v s .<1 \% ; P<0.001$; Table 4$)$. In the 4 milkborne outbreaks linked to schools, milk sold as pasteurized (campylobacter infection and 2 outbreaks of $S$. Enteritidis PT4 infection) was implicated in 3 outbreaks and unpasteurized milk (VTEC O157 infection) in 1. In the latter, initial infection through the consumption of unpasteurized milk was spread from one child to another through person-toperson transmission. There was no difference between outbreaks attributed to unpasteurized milk (12/14; $86 \%)$ and milk sold as pasteurized $(5 / 10 ; 50 \%)$ with regard to associations with farms $(P>0 \cdot 05)$.

\section{Contributory faults}

In four outbreaks more than one fault, thought to have contributed to the outbreak, was reported. Amongst the outbreaks attributed to milk sold as pasteurized, inadequate heat treatment (5) was most 


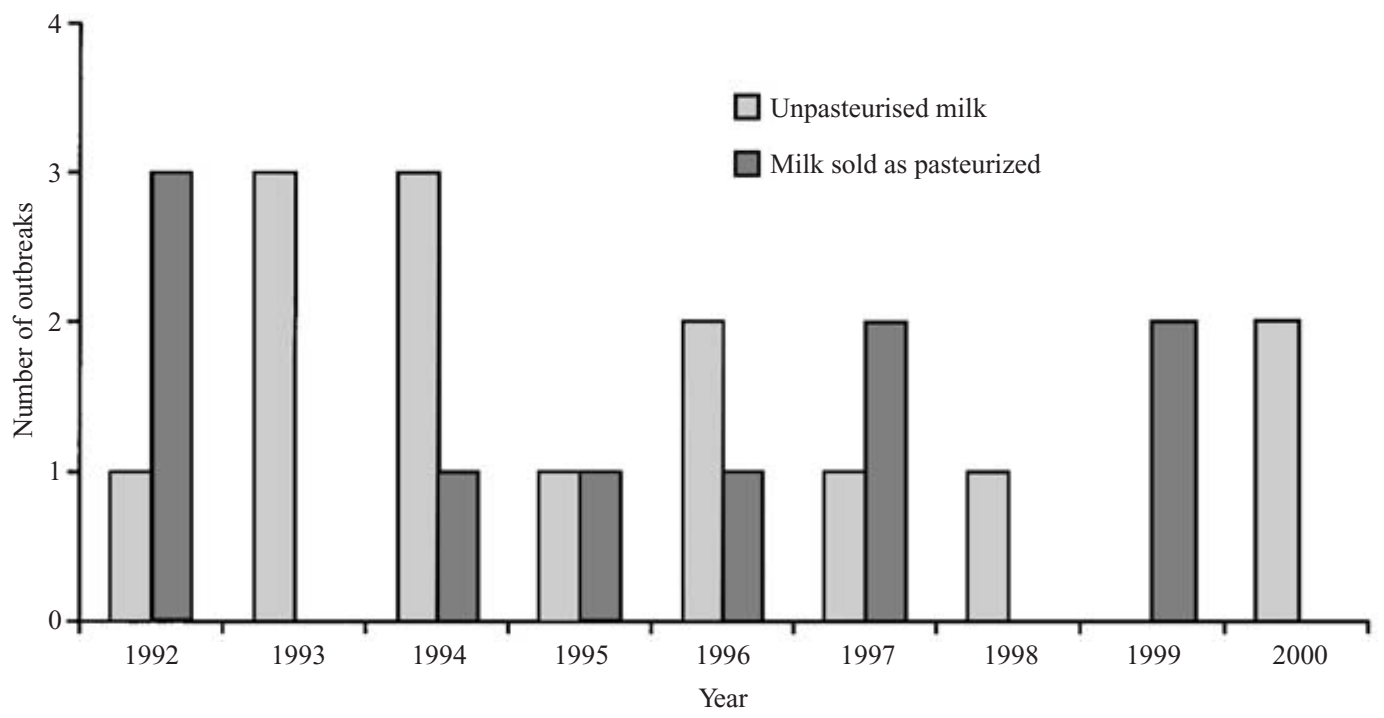

Fig. 1. Milkborne general outbreaks of infectious intestinal disease, England and Wales, 1992-2000. Time trend showing the contribution of pasteurized and unpasteurized milk.

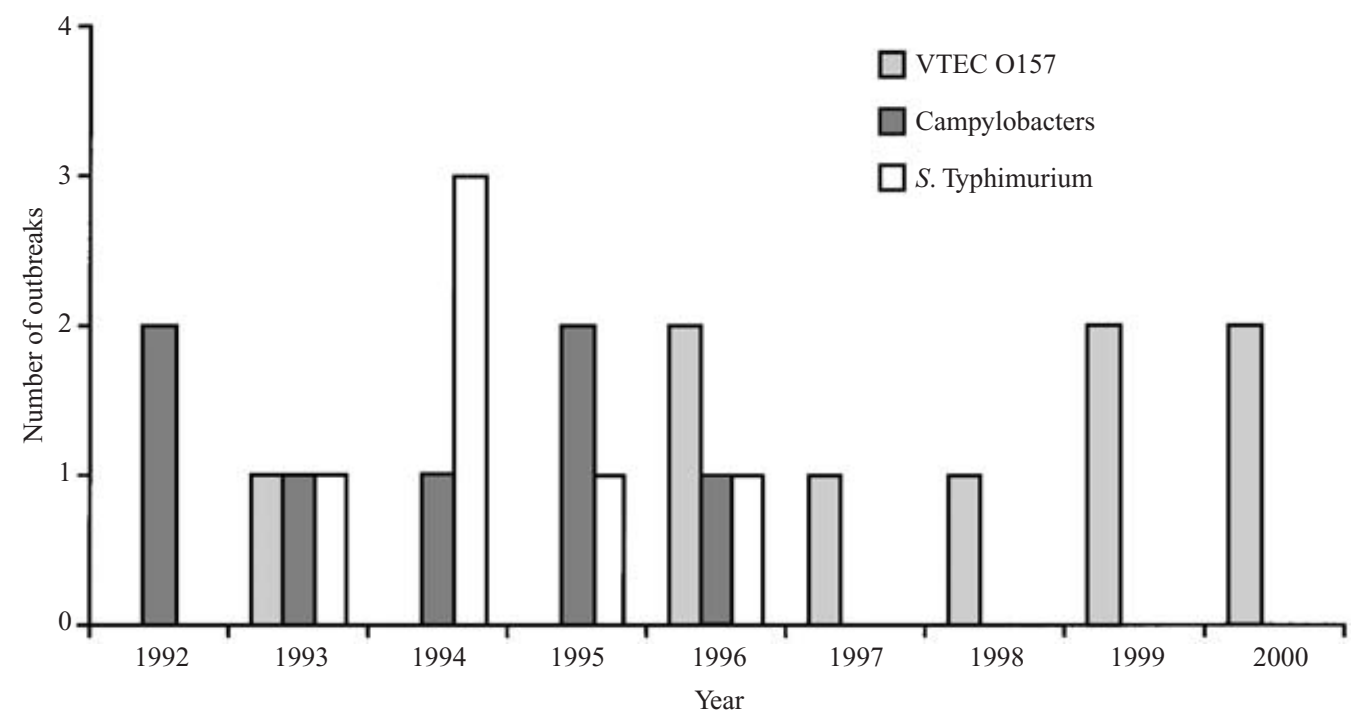

Fig. 2. Milkborne general outbreaks of infectious intestinal disease, England and Wales, 1992-2000. Time trend showing the contribution of VTEC O157, campylobacters and $S$. Typhimurium.

commonly reported, followed by cross contamination (4) and inappropriate storage (2). In one of these outbreaks both inadequate heat treatment and cross contamination was reported. Infected cattle (3) was the most commonly reported fault in unpasteurized milk outbreaks, followed by cross contamination (2) and inappropriate storage (2). No fault was more commonly reported in unpasteurized milk outbreaks (7) than in milk sold as pasteurized outbreaks (1).

\section{Time trends}

Over the surveillance period, the number of milkborne outbreaks as a proportion of all outbreaks of foodborne origin showed no discernible trend $(P>0 \cdot 05)$. Whilst there was no trend in the proportion of outbreaks linked to milk sold as pasteurized $(P>0.05)$ and unpasteurized $(P>0.05)$ milk, with time (Fig. 1), the proportion attributed to VTEC O157 infection increased $(P<0 \cdot 01)$, whilst those attributed to campylobacters decreased $(P<0 \cdot 05)$ (Fig. 2$)$.

\section{Seasonality of milkborne outbreaks}

The date of the first reported onset of symptoms was reported in all 27 milkborne outbreaks, and this was used to calculate the month in which the outbreak took place (Fig. 3). Milkborne outbreaks exhibited 


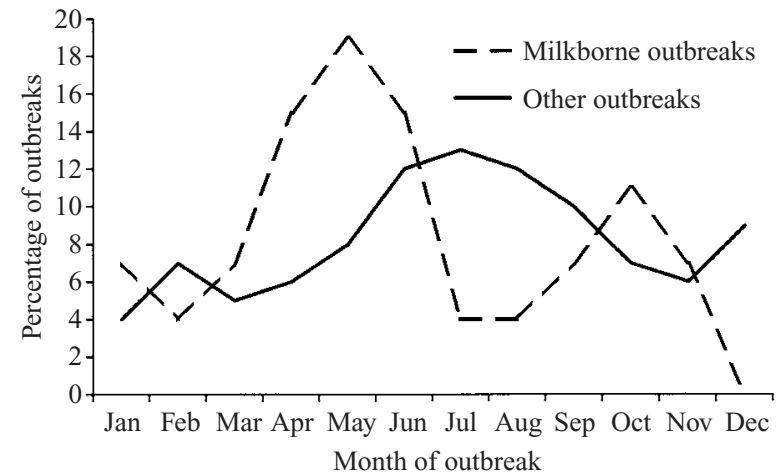

Fig. 3. Seasonality of milkborne general outbreaks of infectious intestinal disease, England and Wales, 1992-2000.

bimodal seasonality, with peaks in late spring/early summer (April to June; $48 \%$ ) and autumn (September to November; $26 \%$ ). Of the 13 outbreaks in late spring/early summer, 6 were attributed to VTEC $\mathrm{O} 157$ and 4 to campylobacters. Unpasteurized milk was reported as the vehicle of infection in 8 of these outbreaks. Of the 7 outbreaks in autumn, 4 were attributed to salmonellas and milk sold as pasteurized reported in 5 .

\section{DISCUSSION}

Between 1 January 1992 and 31 December 2000, milkborne general outbreaks of IID represented a fraction of all outbreaks of foodborne origin reported to CDSC, but were characterized by significant morbidity.

This report highlights the emergence of VTEC O157 as a milkborne pathogen and the continued role of unpasteurized milk in human disease in England and Wales.

Farm animals, and cattle especially, are known reservoirs of VTEC O157 [15]. A 1-year study of faecal rectal samples from recently slaughtered cattle, sheep, pigs and poultry [16] found that $15 \cdot 6 \%$ of 4800 cattle were positive for VTEC O157, and that the prevalence in dairy cattle appeared to be higher than in beef cattle. Furthermore, a detailed longitudinal study of a dairy herd showed that excretion rates varied by season and by the partum, lactation and dietary statuses of the cows [17].

Unpasteurized milk remains an important vehicle of disease in England and Wales. At the time of the Richmond Committee the consumption of raw milk was considered a hazard to human health. However little was known about the prevalence of pathogens in raw milk on retail sale [18]. Two surveys of unpasteurized milk, undertaken by the Department of Health [19] and the PHLS [20], showed evidence of faecal contamination and in some instances food poisoning pathogens were isolated. On the basis of this evidence, the Advisory Committee on the Microbiological Safety of Food (ACMSF) concluded that the sale of raw cows' drinking milk for consumption should be banned [21]. However, following public opposition to the ban, voiced during a subsequent public consultation, the product remained on sale, albeit with tighter checks on its production and marketing [22]. In Scotland, where compulsory heat treatment of raw cows' milk and raw cream for retail sale has been a requirement since 1983, surveillance of outbreaks of all milkborne infections prior to and after the introduction of compulsory pasteurization shows that the risk to consumers has been reduced considerably [23]. The Food Standards Agency in Wales has launched its own 12 week consultation on the sale of raw drinking milk and cream [24]. It remains to be seen how the UK Food Standards Agency, created to 'protect public health from risks which might arise in connection with the consumption of food, and otherwise to protect the interests of consumers in relation to food' [25], will act to control this public health problem in England.

The role of milk, sold as pasteurized, in infection is a cause for concern, especially as the dairy industry has evolved in the UK. Large commercial dairies produce most of the retail milk consumed in the UK, but in many areas milk is also processed and bottled by smaller farm dairies. It is the latter that pose the greatest risk to consumers. The microbiological safety of milk is dependent on the maintenance of equipment (with associated defect monitoring), successful pasteurization of raw milk and maintaining the integrity of milk post-pasteurization. Since effective heat treatment is the critical control point in the pasteurization process it is important to have a rapid monitoring procedure. This is achieved by the alkaline phosphatase test $[6,7]$ which demonstrates that mammalian phosphatase enzyme present in raw milk is inactivated by pasteurization.

Large dairies perform the phosphatase test on every batch of milk prior to release but due to the complexity and cost of the phosphatase test it is not used on a daily basis by small on-farm dairies. The microbiological safety of this product cannot be guaranteed and unfortunately, failures of on-farm pasteurization equipment are not uncommon and have resulted in milk-borne outbreaks of infection $[9,26]$. The real risk 
associated with such failures is unknown. However, studies in the North West of England, in which farmproduced pasteurized milk was monitored during a $2 \cdot 5$ year period from 1999-2001 indicated that $117 /$ 2646 (4\%) of farm-bottled pasteurized milk failed the phosphatase test. Furthermore, during the period of this study 24 of 130 (18\%) on-farm dairies produced milk that failed the phosphatase test, and that was potentially microbiologically unsafe (personal communication, Mrs G. Allen, Preston Public Health Laboratory, MSc thesis). In the absence of timely control checks, farm-bottled milk will continue to be a microbiological safety issue.

The most obvious health protection measure is preventing the contamination of the milk in the first place. In their study of VTEC O157 in dairy cattle [17], Mechie and colleagues isolated the organism from fore milk samples but not from mid stream samples, suggesting that the organism was not secreted by the udder. The authors concluded that thorough teat sanitization and removal of fore milk might prevent contamination of the milk, and this is especially important for unpasteurized milk which will not receive further processing. Although milk sold as pasteurized has a critical control point in the form of heat treatment, producers have no room for complacency as pasteurization failures can occur. In addition, they must take extra precautions to ensure that post-pasteurization contamination does not take place.

The bimodal seasonality of milkborne outbreaks is interesting and may relate to animal husbandry practices. Cattle are often moved out to pasture in springtime and are re-housed in the autumn. The changes in diet or exposure to the environment which may accompany such a transition could have an effect on the carriage and shedding of faecal pathogens $[17,27$, 28]. Such seasonality has clear implications for control, as producers must be aware of the increased risk of contamination at these times of year and must ensure that the control measures, described above, are implemented fully.

Although the burden of infection associated with drinking milk fell over the last century, the emergence of VTEC 0157 reinforces the need for maintaining good controls on milk production. Children, who are particularly vulnerable to VTEC O157 and its sequelae [15], are great consumers of milk. Our analyses show that effective heat treatment is essential and that the process of Hazard Analysis Critical Control Point (HACCP) in the milk production industry is very important. In view of this, there is an imperative for a further review of policy on the sale of unpasteurized milk.

\section{REFERENCES}

1. Department for Environment Food and Rural Affairs, National Statistics. Joint announcement of the Department for Environment, Food and Rural Affairs, Scottish Executive Environment and Rural Affairs Department, Department of Agriculture and Rural Development (Northern Ireland), National Assembly for Wales Agriculture Department. Milk statistics. http://www.defra.gov.uk/esg/Work_htm/Notices/milk. pdf. Accessed 25/1/2002.

2. The Dairy Council. The facts: farming. Available at: http://www.milk.co.uk/. Accessed 31/1/2002.

3. 'Dairy Farming'. Microsoft ${ }^{\mathbb{R}}$ Encarta $^{\mathbb{B}}$ online encyclopedia. Available at: http://encarta.msn.co.uk. Accessed 27/1/2002.

4. Galbraith NS, Forbes P, Clifford C. Communicable disease associated with milk and dairy products in England and Wales 1951-80. BMJ (Clin Res Ed) 1982; 284: 1761-5.

5. Djuretic T, Wall PG, Nichols G. General outbreaks of infectious intestinal disease associated with milk and dairy products in England and Wales: 1992 to 1996. CDR Rev 1997; 7 : R41-5.

6. The Official Journal of the Council of the European Communities. Council Directive 92/46/EEC of 16 June 1992 laying down the health rules for the production and placing on the market of raw milk, heat-treated milk and milk-based products, 1992.

7. Ministry of Agriculture Fisheries and Food, Department of Health, Welsh Office. The Dairy Products (Hygiene) Regulations 1995. London: HMSO, 1995.

8. Food Standards Agency. Food Safety and Standards. www.foodstandards.gov.uk/maff/archive/food/ foodhyg.htm. Accessed 27/2/2002.

9. Anonymous. Outbreak of Vero cytotoxin producing Escherichia coli $\mathrm{O} 157$ infection in north Cumbria. CDR 1999; 9: 95, 98 .

10. Food poisoning outbreak in Japan. http://news.bbc.co.uk/hi/english/world/asia-pacific/newsid_814000/ 814319.stm. Accessed 1/2/2002.

11. Wall PG, de Louvois J, Gilbert RJ, Rowe B. Food poisoning: notifications, laboratory reports, and outbreaks - where do the statistics come from and what do they mean? CDR Rev 1996; 6: R93-100.

12. Djuretic T, Wall PG, Ryan MJ, Evans HS, Adak GK, Cowden JM. General outbreaks of infectious intestinal disease in England and Wales 1992 to 1994. CDR Rev 1996; 6: R57-63.

13. Grant AD, Eke B. Application of information technology to the laboratory reporting of communicable disease in England and Wales. CDR Rev 1993; 3: R75-8.

14. Dean AG, Dean JA, Burton AH, Discker RC. Epi Info, Version 5: a word processing, database, and statistics 
programme for epidemiology on microcomputers. Georgia: USD Inc., 1990.

15. Advisory committee on the Microbiological Safety of Food. Report on Verocytoxin-producing Escherichia coli. London: The Stationery Office, 1995.

16. Chapman PA, Siddons CA, Gerdan Malo AT, Harkin MA. A 1-year study of Escherichia coli O157 in cattle, sheep, pigs and poultry. Epidemiol Infect 1997; 119: 245-50.

17. Mechie SC, Chapman PA, Siddons CA. A 15-month study of Escherichia coli O157: H7 in a dairy herd. Epidemiol Infect 1997; 118: 17-25.

18. Committee on the Microbiological Safety of Food. The microbiological safety of food, part 1. London: HMSO, 1990.

19. Department of Health. Surveillance of the microbiological status of raw cows' milk on retail sale. London: Department of Health, 1998.

20. de Louvois J, Rampling A. One fifth of samples of unpasteurized milk are contaminated with bacteria. BMJ 1998; 316: 625.

21. Advisory Committee on the Microbiological Safety of Food. Annual Report 1998. London: HMSO, 1999.
22. Advisory Committee on the Microbiological Safety of Food. Annual Report 1999. London: HMSO, 2000.

23. Task Force on E. coli O157. Final report. Edinburgh: Scottish Executive Health Department. Food Standards Agency Scotland, 2001.

24. Food Standards Agency. Sale of unpasteurized drinking milk and cream. Available at: http://www.food.gov.uk/foodindustry/Consultations/consultwales/rawmilk cream. Accessed 5/3/2002.

25. Food Standards Agency. About the Agency - aims and values. Food Standards. Agency. 2001. http://www. food.gov.uk. Accessed 21/8/2001.

26. Clark A, Morton S, Wright P, Corkish J, Bolton FJ, Russell J. A community outbreak of Vero cytotoxin producing Escherichia coli O157 infection linked to a small farm dairy. CDR Rev 1997; 7: R206-11.

27. Hancock DD, Besser TE, Kinsel ML, Tarr PI, Rice DH, Paros MG. The prevalence of Escherichia coli O157.H7 in dairy and beef cattle in Washington State. Epidemiol Infect 1994; 113: 199-207.

28. Diez-Gonzalez F, Callaway TR, Kizoulis MG, Russel JB. Grain feeding and the dissemination of acid-resistant Escherichia coli from cattle. Science 1998; 281 : 1666-8. 